\title{
Dry and steam reforming of methane. Comparison and analysis of recently investigated catalytic materials. A short review.
}

\author{
Paulina Summa*, Bogdan Samojeden, Monika Motak \\ AGH University of Science and Technology, Faculty of Energy and Fuels, Al. Mickiewicza 30, 30-059 Kraków, Poland \\ "Corresponding author: e-mail: summa@agh.edu.pl
}

\begin{abstract}
In order to produce valuable syngas, industrial processes of dry reforming of methane and steam reforming of methane must be further developed. This paper is focused on reviewing recently examined catalysts, supporting the mentioned technologies. In both processes the most popular active material choice is usually nickel, due to its good availability. On the other hand, noble metals, such as ruthenium, rhodium or platinum, provide better performance, however the solution is not cost-effective. Materials used as a support influence the catalytic activity. Oxides with basic properties, such as $\mathrm{MgO}, \mathrm{Al}_{2} \mathrm{O}_{3}, \mathrm{CeO}_{2}$, are frequently used as carriers. One of the most promising materials for reforming of methane technologies are hydrotalcites, due to adjustable composition, acid-base properties and possibility of incorporation of various metals and complexes.
\end{abstract}

Keywords: dry methane reforming, steam methane reforming, nickel catalyst, hydrotalcite.

\section{INTRODUCTION}

Nowadays, when the negative results of an industrial development are more visible as environmental changes such as depletion of ozone layer, greenhouse effect and acid rains, substitution of fossil fuels by clean energy sources will be one of the solutions leading to a sustainable energy development. Especially interesting is hydrogen, which could be used as a fuel for the fuel cells, be traditionally combusted with release of environmentally neutral water, or supplied for the production of synthetic fuels which are free from sulphuric ingredients ${ }^{1}$.

Widely used method for a hydrogen production is steam reforming of methane. The volume of hydrogen and efficiency of the process are much more satisfactory than in other methods, for example water splitting through electrolysis which require big energy input ${ }^{2}$. Dry reforming of methane is considered as a way of energy storage through the closed loop thermochemical heat pump ${ }^{4}$. Also, the product of the dry reforming of methane is syngas with carbon monoxide to hydrogen ratio of 1, which makes it a perfect feedstock for Fischer-Tropsch synthesis ${ }^{5}$ which in turn depends on the product selectivity. The kinetics, reactor requirements, control of selectivity and the life of cobalt and iron catalysts are discussed and compared. Control of the FT conditions coupled with appropriate downstream processes results in high yields of gasoline, excellent quality diesel fuel or high value linear $\alpha$-olefins. The history of the various FT options and of the improvements in FT reactor technologies over the last 50 years is reviewed. It appears that "new" technologies are re-discovered in cycles of 15-30 years and it often takes the same time for the implementation of new concepts. Similar type of syngas may be produced via partial oxidation of methane, which is a process competitive to dry reforming, based on a reaction between below-stoichiometric volume of oxygen and methane ${ }^{6}$ based on experimental power rate law equations described in a previous paper and classical kinetics. According to Boudart's school approach of Classical Kinetics, kinetic rate equations of TOM and DRM reactions were then established based on the Quasi-Steady State Approximation (QSSA.
There are a few paths for reforming methane, depending on the initial gas mixture and reforming medium. The methane oxidizing agent may be carbon dioxide, steam or oxygen, according to a provided technique ${ }^{10}$. Catalytic reforming processes are likewise an efficient way for utilization of biogases such as landfill gas, which do not have a production rate constant in time, thus cannot be used as a fuel for a continuous combustion. However, their main ingredient, methane, has a well-known reforming potential ${ }^{11}$.

\section{Dry reforming of methane (DRM)}

Dry reforming of methane is technologically simpler than steam reforming, due to the lack of water evaporation, but with the lower hydrogen production yield ${ }^{12}$. The idea behind this process is to react carbon dioxide with methane in a following way:

$\mathrm{CH}_{4}+\mathrm{CO}_{2} \rightarrow 2 \mathrm{CO}+2 \mathrm{H}_{2} \quad \Delta \mathrm{H}_{298}^{0}=247 \mathrm{~kJ} \cdot \mathrm{mol}^{-1}$

As shown in equation above, methane is a reducing agent and carbon dioxide is an oxidant. This type of reaction may be applied to gases with both $\mathrm{CO}_{2}$ and $\mathrm{CH}_{4}$ content, such as biogases. It is also a method for $\mathrm{CO}_{2}$ mitigation.

There are several side-reactions accompanying DRM process, among them reverse water-gas shift reaction (RWGS) and water-gas shift reaction (WGS), the result of operation conditions, in which water can be generated.

(RWGS) $\mathrm{CO}_{2}+\mathrm{H}_{2} \rightarrow \mathrm{CO}+\mathrm{H}_{2} \mathrm{O}$

$\Delta \mathrm{H}_{298}^{0}=41 \mathrm{~kJ} \cdot \mathrm{mol}^{-1}$

(WGS) $\mathrm{CO}+\mathrm{H}_{2} \mathrm{O} \rightarrow \mathrm{CO}_{2}+\mathrm{H}_{2}$

$\Delta \mathrm{H}^{0}{ }_{298}=-41 \mathrm{~kJ} \cdot \mathrm{mol}^{-1}$

Other inconvenient reactions, especially from the point of view of an applied catalyst, are carbon deposits formation $^{15}$ via the Boudouard reaction or methane decomposition ${ }^{16}$.

(Boudouard) $2 \mathrm{CO} \rightarrow \mathrm{C}+\mathrm{CO}_{2}$

$\Delta \mathrm{H}_{298}^{0}=-171 \mathrm{~kJ} \cdot \mathrm{mol}^{-1}$

(Methane decomposition) $2 \mathrm{CH}_{4} \rightarrow \mathrm{C}+2 \mathrm{H}_{2}$ $\Delta \mathrm{H}^{0}{ }_{298}=75 \mathrm{~kJ} \cdot \mathrm{mol}^{-1}$

The main reforming reaction is highly endothermic, and the whole process requires energy supply and high temperature. At the same time, according to the Le 
Chatelier's principle, the pressure of the process should be low. Temperatures usually applied are in the range of $500-1000^{\circ} \mathrm{C}$ with pressure of $1-20 \mathrm{~atm}^{17} .1000^{\circ} \mathrm{C}$ is a temperature limit because of nickel carbide formation on the catalyst surface. On the other hand, in temperature above $600^{\circ} \mathrm{C}$ the formation of pyrolytic coke over the active surface sites is decreasing the overall activity due to deactivation of the nickel sites ${ }^{\mathbf{1 8}}$. The reactor feed is usually the stoichiometric ratio of carbon dioxide and methane, which results in such conversion that no $\mathrm{CO}_{2}$ recovery is required. It is possible to reach conversion of even 98-99\% with the proper temperature-pressure balance. The higher the temperature and lower the pressure, the process efficiency is closer to $100 \%{ }^{19}$, but at the same time it requires high energy input and an advanced installation which results in high $\operatorname{cost}^{20}$

\section{Steam reforming of methane (SMR)}

The idea behind the steam reforming process is to convert hydrocarbons into a mixture of hydrogen, carbon monoxide, carbon dioxide and methane. It is currently the main industrial process of $\mathrm{H}_{2}$ production. The main SMR reaction can be simplified by the equation below.

$\mathrm{CH}_{4}+\mathrm{H}_{2} \mathrm{O} \rightarrow \mathrm{CO}+3 \mathrm{H}_{2}$

$\Delta \mathrm{H}^{0}{ }_{298}=+206 \mathrm{~kJ} \cdot \mathrm{mol}^{-1}$

A reverse reaction to above equation is also possible and shown below.

$\mathrm{CO}+3 \mathrm{H}_{2} \rightleftarrows \mathrm{CH}_{4}+\mathrm{H}_{2} \mathrm{O}$

$\Delta \mathrm{H}^{0}{ }_{298}=-206.1 \mathrm{~kJ} \cdot \mathrm{mol}^{-1}$

\section{The reaction is performed on a nickel catalyst.}

SMR reaction is highly endothermic. Water-gas shift reaction and methanation reaction are exothermic and reversible at reforming temperature. Steam reforming process is carried out at high temperature range, usually $700-1100^{\circ} \mathrm{C}$.

During the steam reforming of methane (SMR) process, the same carbon forming side-reactions are possible as in the dry reforming process, Boudouard reaction and methane decomposition are reversible at the temperature of the process.

The composition of the produced syngas can be estimated basing on thermodynamic calculations. The $\mathrm{H}_{2} /$ $\mathrm{CO}$ ratio in the final gas mixture is influenced by process parameters such as steam pressure and temperature. Usually pressure inside the reactor is in the range of 3-25 atm, depending on the technology used ${ }^{23}$. The lower the pressure the higher the process efficiency according to the Le Chatelier's principle. Volume balance of products and reagents are important for high conversion - high values of applied temperature and steam-to-carbon ratio are required as steam is oxidizing the coke to carbon oxides, protecting the catalyst from rapid deactivation ${ }^{\mathbf{2 1}}$. On the other hand, modern hydrogen plants are designed to operate with the low steam to carbon ratio of 1.8-2.5 mol steam/ mole $\mathrm{CH}_{4}$ which is beneficial from the point of view of mass flow through the plant, size and costs of the equipment, lower operating costs and higher energy efficiency ${ }^{\mathbf{2 4}}$.

\section{Catalysts for methane reforming processes}

A proper choice of catalytic material influences efficiency of the operation. Both active material and support are important. Different support materials have been investigated, but still the most popular is $\gamma-\mathrm{Al}_{2} \mathrm{O}_{3}{ }^{25}$. The catalyst may have different structure, from powder, grained catalyst to structured forms, such as monolith, honeycomb or open cell foams. The most popular active material is nickel in high concentration. It may be promoted with noble metals such as e.g. platinum. Typical problems for reforming catalysts are sintering and coking.

\section{Dry reforming of methane}

Catalysts for DRM suffer from deactivation caused by catalytic coke. The process is influenced by temperature. Higher rate of coking is promoted by lower temperatures, below $700^{\circ} \mathrm{C}$, where the Boudouard reaction reaches higher rate. Noble metal catalysts showed high activity and good stability against coking. On the other hand, nickel catalysts, showed high activity in DMR process, but they were not resistant against coking ${ }^{26,27}$. Their stability can be improved by preserving small $\mathrm{Ni}$ nanoparticles with strong metal-support interactions ${ }^{28}$ total pressures of 0.1 and $0.5 \mathrm{MPa}$ and $\mathrm{CO}_{2} / \mathrm{CH}_{4}$ ratio of 1 . The kinetic data including carbon formation and deactivation were measured simultaneously by an oscillating microbalance reactor. A microkinetic model was developed to analyze the kinetic data and extended with reactions for the carbon formation (encapsulating and filamentous. This may be achieved on a proper support. NiMgO systems were also investigated, but it is hard to reduce $\mathrm{Ni}^{2+}$ in $\mathrm{NiO}-\mathrm{MgO}$ solid solution ${ }^{\mathbf{1 6}}$.

Noble metal catalysts such as Ir or Ru supported on $\mathrm{Al}_{2} \mathrm{O}_{3}$ usually exhibited high activity and selectivity for reforming of methane. Ni catalyst was initially active but demonstrated worse selectivity and became deactivated rapidly due to coking. Adding small amounts of steam to the feed improved stability of a catalyst and decreased deactivation rate ${ }^{29}$.

The comparison of selected catalysts and their performance in dry reforming was given in Table 1.

Osazuwa et al. ${ }^{\mathbf{3 0}}$ found that the improvement of catalytic performance was possible without the addition of noble metals. Activity and stability were increased by using transition metal catalyst with the perovskite support. The combination of the rare earth metals, transition metals and oxygen in perovskite structure resulted in high catalyst activity and stability. Perovskites have another advantage - high thermal stability. They may also be easily modified by substitution of different cations.

The properties of $\mathrm{Ni}$ and $\mathrm{Ru}$ catalysts supported on $\mathrm{Al}_{2} \mathrm{O}_{3}$ on AISI 316 foam were also tested for the dry reforming process. AISI 316 foam exhibited long-term stability and high catalytic activity. Coating AISI 316 foam with $\mathrm{Al}_{2} \mathrm{O}_{3}$ led to an increase in reactivity. AISI 316 was a foam Fe-based alloy, containing additional elements such as $18 \%$ of $\mathrm{Cr}, 10 \% \mathrm{Ni}$ and $3 \% \mathrm{Mo}$. Ruthenium containing catalyst was reported to exhibit higher activity than the nickel containing one (Table 1). Erdogan et al. ${ }^{31}$ related that although high temperature of $600-1000^{\circ} \mathrm{C}$ and reactant atmosphere may cause some changes in composition of AISI 316 foam matrix, long-term stability remained unaffected.

Natural illite clay enriched in magnesium and applied on a honeycomb monolith was also used as a base for nickel catalyst. The incorporation of nickel and magne- 
Table 1. Comparison of catalyst for dry reforming of methane

\begin{tabular}{|c|c|c|c|c|}
\hline Active Material & Support & Conditions & $\begin{array}{c}\mathrm{CO}_{2} \\
\text { Conversion [\%] }\end{array}$ & References \\
\hline $\mathrm{Ru}(0.5 \%$ wt.) & \multirow{4}{*}{$\mathrm{Al}_{2} \mathrm{O}_{3}$} & \multirow{6}{*}{$\begin{array}{c}\mathrm{p}=1 \mathrm{~atm}, \\
\mathrm{~T}=850^{\circ} \mathrm{C} \\
\text { ratio } \mathrm{CH}_{4}: \mathrm{CO}_{2}=1.3: 1\end{array}$} & 99 & \multirow{6}{*}{19} \\
\hline Rh (5\% wt.) & & & 98 & \\
\hline $\operatorname{Ir}(1 \%$ wt.) & & & 96 & \\
\hline $\mathrm{Pt}(0.5 \%$ wt. $)$ & & & 98 & \\
\hline $\mathrm{NiO}(25-45 \%$ wt.) & $\begin{array}{c}\mathrm{Al}_{2} \mathrm{O}_{3}(45-65 \% \text { wt. })-\mathrm{Ca} \text { aluminate } \\
(3-8 \% \text { wt. })\end{array}$ & & 94 & \\
\hline $\mathrm{Ni}(55-60 \%$ wt.) & kieselguhr & & 93 & \\
\hline $\mathrm{SmCoO}_{3}$ & perovskite & $\begin{array}{l}\mathrm{p}=1 \mathrm{~atm}, \\
\mathrm{~T}=800^{\circ} \mathrm{C} \\
\text { ratio } \mathrm{CH}_{4}: \mathrm{CO}_{2}=1: 1\end{array}$ & 93 & 20 \\
\hline \multirow{2}{*}{ Ru (2\% wt.) } & \multirow[b]{2}{*}{$\mathrm{Al}_{2} \mathrm{O}_{3} / \mathrm{AISI} 316$ foam } & \multirow{2}{*}{$\begin{array}{c}\mathrm{p}=1 \mathrm{~atm} \\
\mathrm{~T}=900^{\circ} \mathrm{C} \\
\text { ratio } \mathrm{CH}_{4}: \mathrm{CO}_{2}=1: 1\end{array}$} & $\mathrm{CH}_{4}$ conversion [\%] & \multirow{3}{*}{21} \\
\hline & & & $>90$ & \\
\hline $\mathrm{Ni}(5 \%$ wt.) & $\mathrm{Al}_{2} \mathrm{O}_{3} / \mathrm{AISI} 316$ foam & $\begin{array}{c}\mathrm{p}=1 \mathrm{~atm}, \\
T=1000^{\circ} \mathrm{C} \\
\text { ratio } \mathrm{CH}_{4}: \mathrm{CO}_{2}=1: 1\end{array}$ & $\sim 89$ & \\
\hline $\begin{array}{l}\mathrm{Ni}(8 \% \text { wt.) } \\
\mathrm{Mg}(3 \% \text { wt. })\end{array}$ & natural illite clay on monolith & $\begin{array}{c}\mathrm{p}=1 \mathrm{~atm}, \\
\mathrm{~T}=1000^{\circ} \mathrm{C} \\
\text { ratio } \mathrm{CH}_{4}: \mathrm{CO}_{2}: \mathrm{O}_{2}=5: 4: 1\end{array}$ & 89 & 22 \\
\hline $\mathrm{Ni}(14 \%$ wt.) & $\begin{array}{l}\text { S-1 coated } \\
\text { SiC support }\end{array}$ & $\begin{array}{c}\mathrm{p}=0.987 \mathrm{~atm}, \\
\mathrm{~T}=750^{\circ} \mathrm{C}, \\
\text { ratio } \mathrm{CH}_{4}: \mathrm{CO}_{2}: \mathrm{O}_{2}=8: 2: 3\end{array}$ & 66 & 23 \\
\hline $\begin{array}{l}\mathrm{K}(0.4 \% \text { wt. }) \\
\mathrm{Ni}(5.3 \% \text { wt.) } \\
\mathrm{Ca}(11.7 \% \text { wt. })\end{array}$ & \multirow[t]{4}{*}{ ZSM-5 } & $\begin{aligned} & \mathrm{p}=1 \mathrm{~atm}, \\
& \mathrm{~T}=800^{\circ} \mathrm{C}, \\
& \text { ratio } \mathrm{CH}_{4}: \mathrm{CO}_{2}: \mathrm{N}_{2}=1: 1: 2.2\end{aligned}$ & $>90$ & 24 \\
\hline Ni:Co in ratio $1: 2$ & & \multirow{3}{*}{$\begin{array}{c}\mathrm{p}=1 \mathrm{~atm} \\
\mathrm{~T}=800^{\circ} \mathrm{C} \\
\text { ratio } \mathrm{CH}_{4}: \mathrm{CO}_{2}: \mathrm{Ar}=1: 1: 3\end{array}$} & $>85$ & \multirow{3}{*}{25} \\
\hline $\mathrm{Ni}: \mathrm{Co}$ in ratio $1: 1$ & & & $>80$ & \\
\hline Co & & & $<80$ & \\
\hline $\mathrm{Ni}$ & hydrotalcite & \multirow{3}{*}{$\begin{array}{c}\mathrm{p}=1 \mathrm{~atm} \\
\mathrm{~T}=550^{\circ} \mathrm{C} \\
\text { ratio } \mathrm{CH}_{4}: \mathrm{CO}_{2}: \mathrm{Ar}=1: 1: 8\end{array}$} & 53 & \multirow[t]{3}{*}{26} \\
\hline $\mathrm{Ni}-\mathrm{Ce}$ & hydrotalcite & & 54.8 & \\
\hline $\mathrm{Ni}-\mathrm{Zr}$ & hydrotalcite & & 25 & \\
\hline $\mathrm{Ni}$ (19\% wt.) & nanocapsular hydrotalcites & $\begin{aligned} \mathrm{p} & =1 \mathrm{~atm} \\
\mathrm{~T} & =800^{\circ} \mathrm{C}\end{aligned}$ & 94 & 28 \\
\hline \multirow{3}{*}{$\mathrm{Ni}$} & CeZr_950 & \multirow{3}{*}{$\begin{array}{c}\mathrm{p}=1 \mathrm{~atm}, \\
\mathrm{~T}=750^{\circ} \mathrm{C} \\
\text { ratio } \mathrm{CH}_{4}: \mathrm{CO}_{2}=0.66: 1\end{array}$} & $\sim 44$ & \multirow{3}{*}{6} \\
\hline & $\mathrm{CeZrNd}_{0.2}{ }^{2} 990$ & & $\sim 57$ & \\
\hline & $\mathrm{CeZrNd}_{0.07 \_1030}$ & & $\sim 58$ & \\
\hline $\mathrm{Ni} 10 \%$ & $\mathrm{La}_{2} \mathrm{Zr}_{2} \mathrm{O}_{7}$ & $\begin{array}{c}\mathrm{p}=1 \mathrm{~atm} \\
\mathrm{~T}=700^{\circ} \mathrm{C} \\
\text { ratio } \mathrm{CH}_{4}: \mathrm{CO}_{2}=1: 1\end{array}$ & $<90$ & 5 \\
\hline $\mathrm{Ni}$ & $\mathrm{SiC}$ foam monolith with CNF's & $\begin{array}{c}\mathrm{p}=0,987 \mathrm{~atm}, \\
\mathrm{~T}=750^{\circ} \mathrm{C} \\
\text { ratio } \mathrm{CH}_{4}: \mathrm{CO}_{2}: \mathrm{Ar}=45: 45: 10\end{array}$ & 75 & 29 \\
\hline
\end{tabular}

sium into the clay increased significantly the density of basic sites. This also results in the increased resistance to coking. Some elements present in clay, e.g. potassium, can promote carbon dioxide activation in $\mathrm{NiO}-\mathrm{MgO}$ solid solution, providing adsorbed oxygen species and carbon monoxide. This type of catalyst was found to have satisfactory stability for 24 hours $^{32}$.

Interesting research was also carried out using zeolites, e.g. silicalite-1 zeolite which was resistant to high temperatures and remained in its crystalline form. It was used as a coating, playing the role of an intermediate between active material and $\mathrm{SiC}$ support. Acidic supports such as zeolites were prone to coke deposition which led to a decrease of activity and shortens their lifetime. S-1, unlike other zeolites, does not have high acidity and was thus more resistant against coking during methane dry reforming than other zeolite materials from this group ${ }^{33}$.

ZSM-5 has also been investigated as a support for DRM. Ni deposited on ZSM-5 was reported to have both good activity and resistance towards coke deposition for 140 hours $^{34}$. Estephane et al. ${ }^{35}$ tested Co and Ni-Co deposited on the ZSM-5. The bimetallic catalyst with cobalt content two times higher than that of nickel gave the best results (Table 1), with the highest activity, stability and low carbon deposits formation after 12 hours.
It was assigned to cobalt playing the role of an oxidizing agent for the removal of carbon species.

Other type of materials studied as catalysts for DRM were hydrotalcites. Both acidic and basic sites may be found on hydrotalcite surface. Gonzalez et. $\mathrm{al}^{\mathbf{3 6}}$ studied nickel-hydrotalcites. The best results were obtained for the highest tested loading of nickel of $19 \mathrm{wt} . \%$. Both activity and selectivity were high, with minimal coke deposition under the optimized conditions of $650^{\circ} \mathrm{C}$. Dębek et. $\mathrm{al}^{37}$ carried out an extensive research on DRM on hydrotalcites. Several types of hydrotalcites were tested, with different content of $\mathrm{Mg}^{2+}$ ions substituted with $\mathrm{Ni}^{2+}$. Moreover, the addition of promoters such as cerium and zirconium was studied. The latter increased the reducibility of nickel species and improved dissociative adsorption of $\mathrm{CO}_{2}$ on the catalyst sites. It should be also mentioned that catalysts were efficient at a relatively low DRM temperature range. Especially $\mathrm{Zr}$ presence impacted strongly both activity and selectivity of the catalys ${ }^{38,39}$ resulting in materials with various $\mathrm{Zr}$ loading. Physicochemical properties of catalysts precursors and final catalysts were investigated via XRF, XRD, low temperature $\mathrm{N}_{2}$ sorption, $\mathrm{H}_{2}-\mathrm{TPR}, \mathrm{CO}_{2}-\mathrm{TPD}, \mathrm{TG}$, SEM and TEM techniques. So characterized catalysts were subsequently tested in the dry methane reforming 
reaction at $550^{\circ} \mathrm{C}$. Zr-loading introduced into brucite-like layers influenced the process of thermal decomposition of HTs and, as a result, their properties and performance in DRM. Although $\mathrm{Zr}$ promotion decreased activity, it strongly increased the stability and selectivity of the catalysts. The catalyst with $\mathrm{Zr}$ species present in the framework of periclase-like mixed oxide exhibited high resistance to coking due to the rearrangement of $\mathrm{Ni}$ particles upon DRM reaction.

La-promoted Ni-hydrotalcite derived catalysts were investigated in a DRM process at low temperatures $\left(550^{\circ} \mathrm{C}\right)$ by Liu et al. ${ }^{41}$. Lanthanum incorporation to the catalyst resulted in enhancing the reforming reaction and direct methane decomposition at given temperature conditions. Also, La supports carbon deposits gasification, which results in lower amount of coke on a surface of the catalyst. Obtained methane conversion during the catalytic test reached $33 \%$ for the $\mathrm{Ni}_{0.215} \mathrm{La}_{0.012} \mathrm{Mg}_{0.535} \mathrm{Al}_{0.238}$ sample at range $550-600^{\circ} \mathrm{C}$, andat $850^{\circ} \mathrm{C}$ the same catalyst showed almost full conversion of methane.

Pappacena et al. ${ }^{14}$ prepared a set of zirconium and neodymium doped catalysts via a surfactant assisted co-precipitation method. The samples varied in the amount of introduced $\mathrm{Nd}$ and $\mathrm{Zr}$. As the catalytic tests showed, the conversion of methane at $750^{\circ} \mathrm{C}$ did not exceeds $60 \%$, but $\mathrm{CO}_{2}$ conversion in given conditions was over $90 \%$. What is important, the dopants do influence the kinetics of the process, especially inhibiting the reverse water-gas shift reaction. $\mathrm{Nd}$ and $\mathrm{Zr}$ addition made it possible to control basicity and surface oxygen mobility while increasing the resistivity of the catalyst against coke formation.
Stabilizing the active material inside the thermally stable structure of oxide such as pyrochlores should lead to the increase in oxygen mobility over the surface and decrease in sintering, though the accessibility of such an active site, locked inside the highly stable structure, may be questionable. Le Sach'e et al. ${ }^{13}$ provided the research on Ni-doped $\mathrm{La}_{2} \mathrm{Zr}_{2} \mathrm{O}_{7}$. The obtained material varied strongly during the stability test - when the catalyst with $5 \%$ Ni lasted only for 30 hours on stream, the one with $10 \% \mathrm{Ni}$ was resistant for 360 hours. Likewise, the catalytic performance in DRM process for $10 \% \mathrm{Ni}$ catalyst was satisfactory, despite the carbon nanotubes formation on the surface.

Gao et al. $^{42}$ focused on a research for a catalyst stable in a DRM process. $\mathrm{Ni}$ as the active material was deposited on the $\mathrm{SiC}$ foam monolith covered with carbon nanofibers. The addition of nanomaterials increased strongly the specific surface area. Such kind of the support provided both high dispersion and strong attachment of the active sites to the surface, which resulted in a catalyst that was resistant for 100 hours on stream.

\section{Steam reforming of methane}

At industrial furnace for methane steam reforming, the reactor inlet temperature is in the range of $450-650^{\circ} \mathrm{C}$ and at the outlet region temperature grows to $850-950^{\circ} \mathrm{C}^{43}$. Thus, a catalyst must be resistant towards sintering, and a chosen support must be temperature-stable and resistant to phase changes ${ }^{44}$.

The comparison of selected catalysts and their performance in steam reforming is given in Table 2 .

Catalysts containing nickel as an active material have been the first choice of studies in the methane steam

Table 2. Comparison of selected catalyst for steam reforming of methane

\begin{tabular}{|c|c|c|c|c|}
\hline Support & Active Material & Conditions & $\begin{array}{c}\text { Methane conversion } \\
{[\%]}\end{array}$ & References \\
\hline $\mathrm{Al}_{2} \mathrm{O}_{3}$ & $\begin{array}{c}\mathrm{Ni}(9.8 \% \text { wt.) S }(4.9 \% \\
\text { wt.) }\end{array}$ & $\begin{array}{c}\mathrm{p}=1 \mathrm{~atm}, \mathrm{~T}=700^{\circ} \mathrm{C}, \mathrm{H}_{2} \mathrm{O}: \mathrm{CH}_{4}: \text { air }= \\
2.5: 1: 3.5\end{array}$ & 99 & 33 \\
\hline $\mathrm{Al}_{2} \mathrm{O}_{3}$ & $\mathrm{Ni}$ (7\% wt.) Mg Al & $\begin{array}{c}\mathrm{p}=0.987 \mathrm{~atm}, \mathrm{~T}=600^{\circ} \mathrm{C} \\
\mathrm{H}_{2} \mathrm{O}: \mathrm{CH}_{4}=2: 1\end{array}$ & $>80$ & \multirow{2}{*}{34} \\
\hline $\mathrm{Al}_{2} \mathrm{O}_{3}$ & $\mathrm{Ni}$ (8.6\% wt.) Zn Al & $\begin{array}{c}\mathrm{p}=0.987 \mathrm{~atm}, \mathrm{~T}=600^{\circ} \mathrm{C} \\
\mathrm{H}_{2} \mathrm{O}: \mathrm{CH}_{4}=2: 1\end{array}$ & $>75$ & \\
\hline $\mathrm{SiO}_{2}$ & 10 (\% wt.) nano-NiO & $\begin{array}{c}\mathrm{p}=1 \mathrm{~atm}, \mathrm{~T}=700^{\circ} \mathrm{C} \\
\mathrm{H}_{2} \mathrm{O}: \mathrm{CH}_{4}=3.5: 1\end{array}$ & 95.7 & 35 \\
\hline $\mathrm{SiO}_{2}$ & $\mathrm{Ni}(10 \%$ wt.) & $\begin{array}{c}\mathrm{p}=1 \mathrm{~atm}, \mathrm{~T}=700^{\circ} \mathrm{C} \\
\mathrm{H}_{2} \mathrm{O}: \mathrm{CH}_{4}=2: 1\end{array}$ & $>35$ & 36 \\
\hline $\mathrm{CeO}_{2}$ & Rh (1.5\% wt.) & $\begin{array}{c}p=1 \mathrm{~atm}, \mathrm{~T}=635^{\circ} \mathrm{C} \\
\mathrm{H}_{2} \mathrm{O}: \mathrm{CH}_{4}=3.5: 1\end{array}$ & $>99$ & \multirow{6}{*}{37} \\
\hline $\mathrm{Al}_{2} \mathrm{O}_{3}$ & Rh (1.5\% wt.) & $\mathrm{p}=1 \mathrm{~atm}, \mathrm{~T}=660^{\circ} \mathrm{C}, \mathrm{H}_{2} \mathrm{O}: \mathrm{CH}_{4}=3.5: 1$ & $>99$ & \\
\hline $\mathrm{CeO}_{2}$ & Ru (1.5\% wt.) & $\mathrm{p}=1 \mathrm{~atm}, \mathrm{~T}=699^{\circ} \mathrm{C}, \mathrm{H}_{2} \mathrm{O}: \mathrm{CH}_{4}=3.5: 1$ & 96.8 & \\
\hline $\mathrm{Al}_{2} \mathrm{O}_{3}$ & Ru (1.5\% wt.) & $\mathrm{p}=1 \mathrm{~atm}, \mathrm{~T}=699^{\circ} \mathrm{C}, \mathrm{H}_{2} \mathrm{O}: \mathrm{CH}_{4}=3.5: 1$ & $>99$ & \\
\hline $\mathrm{CeO}_{2}$ & $\mathrm{Pt}(1.1 \% \mathrm{wt})$. & $\mathrm{p}=1 \mathrm{~atm}, \mathrm{~T}=800^{\circ} \mathrm{C}, \mathrm{H}_{2} \mathrm{O}: \mathrm{CH}_{4}=3.5: 1$ & $<80$ & \\
\hline $\mathrm{Al}_{2} \mathrm{O}_{3}$ & $\mathrm{Pt}(1.1 \%$ wt. $)$ & $\mathrm{p}=1 \mathrm{~atm}, \mathrm{~T}=745^{\circ} \mathrm{C}, \mathrm{H}_{2} \mathrm{O}: \mathrm{CH}_{4}=3.5: 1$ & $>99$ & \\
\hline $\mathrm{MgO}$ & $\mathrm{Ru}$ & $\mathrm{p}=1 \mathrm{~atm}, \mathrm{~T}=750^{\circ} \mathrm{C}, \mathrm{H}_{2} \mathrm{O}: \mathrm{CH}_{4}=2.8: 3$ & $>98$ & \multirow[t]{2}{*}{38} \\
\hline $\mathrm{Nb}_{2} \mathrm{O}_{5}$ & $\mathrm{Ru}$ & $\mathrm{p}=1 \mathrm{~atm}, \mathrm{~T}=700^{\circ} \mathrm{C}, \mathrm{H}_{2} \mathrm{O}: \mathrm{CH}_{4}=2.8: 3$ & $>99$ & \\
\hline metal foam & $\begin{array}{l}\operatorname{Pd}(1.15 \% \text { wt. })- \\
\operatorname{Rh}(0.16 \% \text { wt.) }\end{array}$ & $\mathrm{p}=1 \mathrm{~atm}, \mathrm{~T}=750^{\circ} \mathrm{C}, \mathrm{H}_{2} \mathrm{O}: \mathrm{CH}_{4}=2.5: 1$ & 96.7 & 39 \\
\hline $\begin{array}{l}\text { spirally wound } \\
\text { honeycombe }\end{array}$ & Ni foil & $\mathrm{p}=1 \mathrm{~atm}, \mathrm{~T}=800^{\circ} \mathrm{C}, \mathrm{H}_{2} \mathrm{O}: \mathrm{CH}_{4}=1.34: 1$ & $>97$ & 40 \\
\hline $\begin{array}{l}\mathrm{La}\left(3 \% \text { wt.) }-\mathrm{Al}_{2} \mathrm{O}_{3}\right. \\
\text { (ceramic monolith 100cpsi) }\end{array}$ & Ru (1.5\% wt.) & \multirow{2}{*}{$\begin{array}{c}\mathrm{P}=1 \mathrm{~atm}, \mathrm{~T}=800^{\circ} \mathrm{C} \\
\mathrm{H}_{2} \mathrm{O} / \mathrm{C}: 3: 1\end{array}$} & $>99$ & \multirow{2}{*}{41} \\
\hline $\begin{array}{l}\mathrm{La}(3 \% \text { wt. })-\mathrm{Al}_{2} \mathrm{O}_{3} \\
\text { (ceramic monolith } 170 \\
\text { cpsi) }\end{array}$ & $\mathrm{Ru}(1.5 \%$ wt.) & & $>99.5$ & \\
\hline La & NCZO & $\mathrm{p}=1 \mathrm{~atm}, \mathrm{~T}=900^{\circ} \mathrm{C}, \mathrm{H}_{2} \mathrm{O}: \mathrm{CH}_{4}: \mathrm{N}_{2}=1: 1: 3$ & 95 & 42 \\
\hline Ru (3\%wt.) & $\mathrm{ZnLaAlO}_{4}$ & $\mathrm{p}=1 \mathrm{~atm}, \mathrm{~T}=800^{\circ} \mathrm{C}, \mathrm{H}_{2} \mathrm{O}: \mathrm{CH}_{4}: \mathrm{N}_{2}=1: 1: 3$ & $<99$ & 43 \\
\hline $\mathrm{Ni}$ & $50 \%$ Ce $50 \% \mathrm{Ti}$ & $\mathrm{p}=1 \mathrm{~atm}, \mathrm{~T}=500^{\circ} \mathrm{C}, \mathrm{H}_{2} \mathrm{O}: \mathrm{CH}_{4}: \mathrm{N}_{2}=1: 1$ & $>60$ & 44 \\
\hline $\mathrm{BrNi}_{1.6}$ & $\begin{array}{c}\mathrm{ZrO}_{2} \\
\text { hollow shell } \\
\end{array}$ & $\mathrm{p}=1 \mathrm{~atm}, \mathrm{~T}=750^{\circ} \mathrm{C}, \mathrm{H}_{2} \mathrm{O}: \mathrm{CH}_{4}=2.5: 1$ & $<99$ & 45 \\
\hline
\end{tabular}


reforming process. $\mathrm{Ni}$ supported on $\mathrm{Al}_{2} \mathrm{O}_{3}$ is a promising catalyst, due to its low price and significant activity ${ }^{45,28}$. Catalytic activity of $\mathrm{Ni} / \mathrm{Al}_{2} \mathrm{O}_{3}$ was found to increase with nickel content because of the increasing number of sites. On the other hand, the more nickel sites the higher their aggregation. A typical nickel content in a catalyst for steam reforming was ca. $12 \mathrm{wt} \%$ to avoid aggregation and decrease sintering during the process. Bej et al. ${ }^{\mathbf{4 6}}$ prepared a catalyst on the $\mathrm{SiO}_{2}$ support with nano-NiO as an active material. Highly dispersed nickel oxide was introduced by the sol-gel method. The obtained catalyst showed stable methane conversion for 3.5 hours. Zhang et al. ${ }^{47}$ investigated likewise $10 \% \mathrm{Ni} / \mathrm{SiO}_{2}$ catalyst, however instead of calcination, it was treated with DBD plasma for 1 hour. The overall conversion of methane did not exceed $40 \%$ but stability test resulted in 7 hours on stream.

The promotion of an SMR catalyst with other metals may also have a positive impact on its performance. Nieva et al. ${ }^{48}$ studied the addition of zinc and magnesium to nickel-alumina catalyst at low temperature steam reforming. Ni-Zn-Al catalyst showed higher activity than $\mathrm{Ni}-\mathrm{Mg}-\mathrm{Al}$, with the lower ratio of coking. It was found, however, that zinc sublimated during steam reforming, and thus the catalyst had to be activated at $600^{\circ} \mathrm{C}$. No $\mathrm{Ni}$ sintering was registered which was assigned to metalsupport interactions preventing migration.

Nickel catalysts required usually higher active material loading as compared to noble metals, the latter being at the range of $1-2 \%$. Amjad et al. ${ }^{49}$ studied the application of $\mathrm{Rh}, \mathrm{Ru}$ and $\mathrm{Pt}$ on different supports, such as $\mathrm{Al}_{2} \mathrm{O}_{3}$ and $\mathrm{CeO}_{2}$, in the methane steam reforming process. The best performance, high activity at low temperature (ca. $600^{\circ} \mathrm{C}$ ) and good selectivity to methane was found for $1.5 \% \mathrm{Rh} / \mathrm{CeO}_{2}$. This catalyst generated hydrogen-rich gas with low concentration of carbon monoxide, which was crucial from the point of view of hydrogen production. Other materials also showed satisfactory performance. $\mathrm{Ru}$ deposited on the $\mathrm{Al}_{2} \mathrm{O}_{3}$ reached full conversion at $699^{\circ} \mathrm{C}$, Pt deposited on $\mathrm{CeO}_{2}$ at $745^{\circ} \mathrm{C}$. As shown in Table 2, the worst result was obtained for $\mathrm{Pt}$ on $\mathrm{Al}_{2} \mathrm{O}_{3}$, which did not show methane conversion higher than $80 \%$.

$\mathrm{Ru}$-based catalysts were reported to have high activity and selectivity during the steam reforming of methane. They remained resistant towards coking and sintering even at high temperatures $\left(800^{\circ} \mathrm{C}\right)$. Amjad et al. ${ }^{\mathbf{5 0}}$ studied $\mathrm{Ru}$ on different supports $-\mathrm{MgO}$ and $\mathrm{Nb}_{2} \mathrm{O}_{5}$ were chosen. $\mathrm{MgO}$ -based catalyst had good activity in terms of $\mathrm{CH}_{4}$ conversion. Niobia provided strong bonding between the metal and the support. $\mathrm{Nb}_{2} \mathrm{O}_{5}$ catalysts showed very good activity, most of them with full conversion in the range of $700-750^{\circ} \mathrm{C}$.

Metal foam have been investigated lately as a useful material for steam reforming of methane. Due to an appropriate porous structure and possibility of preparation in a desired shape, with low heat capacity and high heat transfer, they reduced the formation of the hot spots inside the reactor. Another advantage of metal foam was that its application can reduce the pressure drop in a reactor and provide a better mixing of gases. $\mathrm{Pd}-\mathrm{Ru}$ catalyst supported on a metal foam were studied by Roy et. $\mathrm{al}^{51}$. The investigated catalysts compared to the commercial ones, such as $13 \%$ wt. $\mathrm{Ni} / \mathrm{Al}_{2} \mathrm{O}_{3}$ and $8 \%$ $\mathrm{Ru} / \mathrm{Al}_{2} \mathrm{O}_{3}$, showed better activity, $\mathrm{H}_{2}$ yield and competitive stability. After 200 hours experiment, negligible traces of coke were found on the surface.

Catalysts in the form of nickel on honeycomb were also investigated. The catalyst was built of $30 \mu \mathrm{m}$-thin nickel foil in the form of metallic honeycomb without the addition of either alumina or noble metals. The catalyst showed high conversion, as well as high hydrogen yield. Hardly were any carbon deposits detected on the surface. Ni oxidation led to gradual deactivation of the catalyst, but flowing hydrogen resulted in rapid regeneration. Temperature profiles confirmed good heat transfer between the catalyst and the surrounding gases ${ }^{\mathbf{5 2}}$.

$\mathrm{Ru}$ supported on ceramic monoliths with a different number of channels per square inch, covered with $\alpha$-alumina coating modified with La was studied by Vita et al. Two catalysts, one with square and the second with hexagonal channels showed good performance during the process, reaching fast equilibrium methane conversion, with slightly better results for the monolith with higher cell density ${ }^{53}$.

$\mathrm{Ni}-\mathrm{Ce}_{0.8} \mathrm{Zr}_{0.2} \mathrm{O}_{2}$ based materials with different dopants such as $\mathrm{Mg}, \mathrm{Ca}$, La and were examined. The best catalytic performance was obtained by the La-containing catalyst, due to very high Ni dispersion, strong interaction between active material and support. Moreover, La provides the strongest basicity from the investigated samples. According to Khani et al. ${ }^{\mathbf{5 4}}$ mixing ruthenium as an active material with lanthanum containing support led to superlative catalyst, providing not only excellent conversion but likewise good stability with 30 hours on stream, working with a conversion higher than $95 \%$ all that time.

Mixed oxides of cerium and titanium were prepared by the two different methods: sol-gel and flame spray pyrolysis, to compare their activity and stability in SMR process. The better results were obtained by catalysts prepared through sol-gel method, especially these containing more cerium than titanium. It was noted, that the samples prepared by sol-gel method were more stable during the stability tests ${ }^{55}$.

Lim et al. ${ }^{\mathbf{5 6}}$ investigated the influence of porosity on the catalytic performance in SMR process. The best results were obtained by the samples with medium values of $\mathrm{S}_{\mathrm{BET}}$ from the compared ones, about $176-178 \mathrm{~m}^{2} / \mathrm{g}$, and medium total pore volume, $0.48-0.52 \mathrm{~cm}^{3} / \mathrm{g}$. This type of an active material was resistant during 48 hours on stream, resulting in very high conversion all this time.

On the other hand, it was found that in steam reforming zeolites should not be used, as they were thermally stable only up to $600^{\circ} \mathrm{C}$, with water vapor damaging their structure over this temperature ${ }^{57,58}$.

\section{CONCLUSIONS}

Dry reforming of methane and steam reforming of methane could lead to the improvement of the quality of biogas and enable the utilization of landfill gas, in the latter case leading to added-value products. Research on active, stable and selective catalyst for both dry reforming of methane and steam reforming of methane is dominated by the nickel-containing materials, supported on basic oxides, very often modified. Doping with lanthanum, rhodium and ruthenium provides satisfactory activity 
and stability, but it is leads to increased costs of materials used. The catalysts for DRM and SMR can suffer deactivation due to active metal sintering and carbon deposition. The problem of sintering may be solved by preserving small metal particles over the catalyst surface by providing strong interaction with the support. Carbon deposition could be reduced through increasing the content of steam in a feedstock and optimizing temperature conditions of the process. In this respect, materials based on Ni-hydrotalcites are of special interest due to low costs of precursors, simplicity of preparation followed by the satisfactory activity and selectivity towards the reaction. High activity of such materials results from their basic properties, which may be tailored through appropriate composition. Their high stability towards sintering arises from strong interaction between active metal and support. High stability towards carbon deposits formation can be reached via appropriate promotion, e.g. with $\mathrm{La}$ or $\mathrm{Zr}$. A lot of promising catalysts were investigated, but the most important aspect is optimization of costs of their production and exploitation. The accessibility of materials and repeatability of a catalyst production are of special importance, in order to apply a catalyst on industrial scale.

\section{LITERATURE CITED}

1. Rostrup-Nielsen, J.R. (2004) Fuels and energy for the future: The role of catalysis Catal Rev - Sci Eng, https://doi. org/10.1081/CR-200036716.

2. Turner, J.A. (2004) Sustainable hydrogen production Science (80- ), https://doi.org/10.1126/science.1103197.

3. Samojeden, B. (2018). The current and future trends in chemical CO2 utilization In: Contemp. Probl. Power Eng. Environ. Prot. 2017 222-226.

4. Fish, J.D. \& Hawn, D.C. (1987). Closed Loop Thermochemical Energy Transport Based on CO2 Reforming of Methane: Balancing the Reaction Systems J. Sol. Energy Eng. 109(3) 215, https://doi.org/10.1115/1.3268209.

5. Dry, M.E. (2002). The Fischer-Tropsch process: 1950-2000 Catal Today 71(3-4) 227-241, https://doi.org/10.1016/S09205861(01)00453-9.

6. Nguyen, T.H., Łamacz, A., Krztoń, A., Liszka, B., \& Djéga-Mariadassou, G. (2016). Partial oxidation of methane over $\mathrm{Ni0} / \mathrm{La}_{2} \mathrm{O}_{3}$ bifunctional catalyst III. Steady state activity of methane total oxidation, dry reforming, steam reforming and partial oxidation. Sequences of elementary steps Appl. Catal. B. Environ., https://doi.org/10.1016/j.apcatb.2015.09.016.

7. Nguyen, T.H., Łamacz, A., Krztoń, A., Ura, A., Chałupka, K., Nowosielska, M., Rynkowski, J. \& Djéga-Mariadassou, G. (2015). Partial oxidation of methane over Ni0/La2O3 bifunctional catalyst II: Global kinetics of methane total oxidation, dry reforming and partial oxidation Appl. Catal. B. Environ., https://doi.org/10.1016/j.apcatb.2014.10.019.

8. Nguyen, T.H., Łamacz, A., Beaunier, P., Czajkowska, S., Domański, M., Krztoń, A., Van Le, T. \& Djéga-Mariadassou, G. (2014). Partial oxidation of methane over bifunctional catalyst I. In situ formation of $\mathrm{Ni} / \mathrm{La} 2 \mathrm{O} 3$ during temperature programmed POM reaction over LaNiO3perovskite Appl. Catal. B. Environ., https://doi.org/10.1016/j.apcatb.2014.01.053.

9. Nguyen, T.H., Łamacz, A., Krztoń, A. \& Djéga-Mariadassou, G. (2016). Partial oxidation of methane over Ni0/La2O3 bifunctional catalyst IV: Simulation of methane total oxidation, dry reforming and partial oxidation using the Quasi-Steady State Approximation Appl. Catal. B. Environ., https://doi. org/10.1016/j.apcatb.2016.06.034.

10. Ghoneim, S.A., El-Salamony, R.A. \& El-Temtamy, S.A. (2016). Review on Innovative Catalytic Reforming of Natural
Gas to Syngas World J Eng Technol, https:/doi.org/10.4236/ wjet.2016.41011.

11. Rathod, V. \& Bhale, P.V. (2014). Experimental investigation on biogas reforming for syngas production over an alumina based nickel catalyst Energy Procedia, https://doi.org/10.1016/j. egypro.2014.07.267.

12. Buelens, L.C., Galvita, V.V., Poelman, H., Detavernier, C. \& Marin, G.B. (2016). Super-dry reforming of methane intensifies $\mathrm{CO} 2$ utilization via le Chatelier's principle Science (80- ), https://doi.org/10.1126/science.aah7161.

13. le Saché, E., Pastor-Pérez, L., Watson, D., Sepúlveda-Escribano, A. \& Reina, T.R. (2018). Ni stabilised on inorganic complex structures: superior catalysts for chemical CO2recycling via dry reforming of methane Appl. Catal. B. Environ., https:// doi.org/10.1016/j.apcatb.2018.05.051.

14. Pappacena, A., Razzaq, R., de Leitenburg, C., Boaro, M., \& Trovarelli, A. (2018). The Role of Neodymium in the Optimization of a Ni/CeO2 and Ni/CeZrO2 Methane Dry Reforming Catalyst Inorganics, https://doi.org/10.3390/inorganics6020039.

15. Pakhare, D. \& Spivey, J. (2014). A review of dry (CO2) reforming of methane over noble metal catalysts Chem Soc Rev, https://doi.org/10.1039/c3cs60395d.

16. Littlewood, P., Xie, X., Bernicke, M., Thomas, A. \& Schomäcker, R. (2015). Ni0.05Mn0.95O catalysts for the dry reforming of methane Catal Today, https://doi.org/10.1016/j. cattod.2014.07.054.

17. Oyama, S.T., Hacarlioglu, P., Gu, Y., \& Lee, D. (2012). Dry reforming of methane has no future for hydrogen production: Comparison with steam reforming at high pressure in standard and membrane reactors Int J Hydrogen Energy, https://doi.org/10.1016/j.ijhydene.2011.09.149.

18. Ginsburg, J.M., Piña, J., El Solh, T. \& De Lasa, H.I. (2005). Coke formation over a nickel catalyst under methane dry reforming conditions: Thermodynamic and kinetic models Ind. Eng. Chem. Res., https://doi.org/10.1021/ie0496333.

19. Usman, M., Wan Daud, WMA. \& Abbas, HF. (2015). Dry reforming of methane: Influence of process parameters A review Renew Sustain Energy Rev., https://doi.org/10.1016/j. rser.2015.02.026.

20. Luyben, W.L. (2014). Design and control of the dry methane reforming process Ind. Eng. Chem. Res., https://doi. org/10.1021/ie5023942.

21. Harshini, D., Kwon, Y., Han, J., Yoon, S.P., Nam, S.W. \& Lim, T.H. (2010). Suppression of carbon formation in steam reforming of methane by addition of $\mathrm{Co}$ into $\mathrm{Ni} /$ ZrO2 catalysts Korean J. Chem. Eng., https://doi.org/10.2478/ s11814-010-0095-9.

22. Hu, D., Gao, J., Ping, Y., Jia, L., Gunawan, P., Zhong, Z., Xu, G., Gu, F. \& Su, F. (2012). Enhanced investigation of $\mathrm{CO}$ methanation over $\mathrm{Ni} / \mathrm{Al} 2 \mathrm{O} 3$ catalysts for synthetic natural gas production Ind. Eng. Chem. Res., https://doi.org/10.1021/ ie300049f.

23. Rostrup-Nielsen, JR. (1984). Catalytic Steam Reforming Catalysis, https://doi.org/10.1007/978-3-642-93247-2_1.

24. Rostrup-Nielsen, JR. \& Sehested, J. (2003). Steam Reforming for Hydrogen. The Process and the Mechanism ACS Div. Fuel. Chem. Prepr., https://doi.org/10.1021/ma0001180.

25. Choi, J.S., Moon, K.I., Kim, Y.G., Lee, J.S., Kim, C.H. \& Trimm, D.L. (1998). Stable carbon dioxide reforming of methane over modified Ni/Al2O3 catalysts Catal. Letters 52(1-2) 43-47, https://doi.org/10.1023/A:1019002932509.

26. Wang, C., Sun, N., Zhao, N., Wei, W., Sun, Y., Sun, C., Liu, H. \& Snape, CE. (2015). Coking and deactivation of a mesoporous $\mathrm{Ni}-\mathrm{CaO}-\mathrm{ZrO} 2$ catalyst in dry reforming of methane: A study under different feeding compositions Fuel, https://doi.org/10.1016/j.fuel.2014.11.097.

27. Tarasov, A., Düdder, H., Mette, K., Kühl, S., Kähler, K., Schlögl, R., Muhler, M. \& Behrens, M. (2014). Investigation of coking during dry reforming of methane by means 
of thermogravimetry Chemie-Ingenieur-Technik, https://doi. org/10.1002/cite.201400092.

28. Chen, D., Lødeng, R., Anundskås, A., Olsvik, O. \& Holmen, A. (2001). Deactivation during carbon dioxide reforming of methane over Ni catalyst: Microkinetic analysis Chem. Eng. Sci., https://doi.org/10.1016/S0009-2509(00)00360-2.

29. Muradov, N. \& Smith, F. (2008). Thermocatalytic conversion of landfill gas and biogas to alternative transportation fuels Energy and Fuels, https://doi.org/10.1021/ef8000532.

30. Osazuwa, O.U., Setiabudi, H.D., Rasid, R.A. \& Cheng, C.K. (2017). Syngas production via methane dry reforming: A novel application of $\mathrm{SmCoO} 3$ perovskite catalyst J. Nat. Gas. Sci. Eng., https://doi.org/10.1016/j.jngse.2016.11.060.

31. Erdogan, B., Arbag, H. \& Yasyerli, N. (2018). SBA-15 supported mesoporous $\mathrm{Ni}$ and Co catalysts with high coke resistance for dry reforming of methane Int J Hydrogen Energy, https://doi.org/10.1016/j.ijhydene.2017.11.127.

32. Akri, M., Achak, O., Granger, P., Wang, S., BatiotDupeyrat, C. \& Chafik, T. (2018). Autothermal reforming of model purified biogas using an extruded honeycomb monolith: A new catalyst based on nickel incorporated illite clay promoted with $\mathrm{MgO}$ J Clean Prod, https://doi.org/10.1016/j. jclepro.2017.09.251.

33. Wei, Q., Yang, G., Gao, X., Yamane, N., Zhang, P., Liu, G. \& Tsubaki, N. (2017). Ni/Silicalite-1 coating being coated on $\mathrm{SiC}$ foam: A tailor-made monolith catalyst for syngas production using a combined methane reforming process Chem. Eng. J., https://doi.org/10.1016/j.cej.2017.06.109.

34. Chang, J.S., Park, S.E. \& Chon, H. (1996). Catalytic activity and coke resistance in the carbon dioxide reforming of methane to synthesis gas over zeolite-supported Ni catalysts Appl. Catal. A Gen. https://doi.org/10.1016/0926-860X(96)00150-0.

35. Estephane, J., Aouad, S., Hany, S., El Khoury, B., Gennequin, C., El Zakhem, H., El Nakat, J., Aboukaïs, A. \& Abi Aad, E. (2015). CO2 reforming of methane over Ni-Co/ZSM5 catalysts. Aging and carbon deposition study Int. J. Hydrogen Energy 40(30) 9201-9208.

36. González, A.R., Asencios, Y.J.O., Assaf, E.M. \& Assaf, J.M. (2013). Dry reforming of methane on Ni-Mg-Al nano-spheroid oxide catalysts prepared by the sol-gel method from hydrotalcite-like precursors Appl. Surf. Sci., https://doi. org/10.1016/j.apsusc.2013.05.082.

37. Dębek, R., Motak, M., Galvez, M.E., Da Costa, P. \& Grzybek, T. (2017). Catalytic activity of hydrotalcite-derived catalysts in the dry reforming of methane: on the effect of $\mathrm{Ce}$ promotion and feed gas composition React Kinet Mech Catal, https://doi.org/10.1007/s11144-017-1167-1.

38. Dębek, R., Galvez, M.E., Launay, F., Motak, M., Grzybek, T. \& Da Costa, P. (2016). Low temperature dry methane reforming over $\mathrm{Ce}, \mathrm{Zr}$ and $\mathrm{CeZr}$ promoted $\mathrm{Ni}-\mathrm{Mg}-\mathrm{Al}$ hydrotalcite-derived catalysts Int. J. Hydrogen Energy, https:// doi.org/10.1016/j.ijhydene.2016.02.074.

39. Dębek, R., Motak, M., Galvez, M.E., Grzybek, T. \& Da Costa, P. (2018). Promotion effect of zirconia on $\mathrm{Mg}(\mathrm{Ni}, \mathrm{Al})$ $\mathrm{O}$ mixed oxides derived from hydrotalcites in $\mathrm{CO}_{2}$ methane reforming Appl. Catal. B. Environ., https://doi.org/10.1016/j. apcatb.2017.06.024.

40. Dębek, R., Radlik, M., Motak, M., Galvez, M.E., Turek, W., Da Costa, P. \& Grzybek, T. (2015). Ni-containing Ce-promoted hydrotalcite derived materials as catalysts for methane reforming with carbon dioxide at low temperature On the effect of basicity Catal Today, https://doi.org/10.1016/j. cattod.2015.03.017.

41. Liu, H., Wierzbicki, D., Debek, R., Motak, M., Grzybek, T., Da Costa, P. \& Gálvez, ME. (2016). La-promoted Nihydrotalcite-derived catalysts for dry reforming of methane at low temperatures Fuel, https://doi.org/10.1016/j.fuel.2016.05.073.

42. Gao, X., Liu, G., Wei, Q., Yang, G., Masaki, M., Peng, X., Yang, R. \& Tsubaki, N. (2017). Carbon nanofibers decorated $\mathrm{SiC}$ foam monoliths as the support of anti-sintering $\mathrm{Ni}$ catalyst for methane dry reforming Int. J. Hydrogen Energy, https://doi.org/10.1016/j.ijhydene.2017.05.164.

43. de Souza, V.P., Costa, D., dos Santos, D., Sato, A.G. \& Bueno J.M.C. (2012). Pt-promoted $\alpha$-Al2O3-supported Ni catalysts: Effect of preparation conditions on oxi-reduction and catalytic properties for hydrogen production by steam reforming of methane Int J Hydrogen Energy 37(13) 9985-9993, https:// doi.org/10.1016/J.IJHYDENE.2012.03.141.

44. Jabbour, K., Massiani, P., Davidson, A., Casale, S. \& El Hassan, N. (2017). Ordered mesoporous "one-pot" synthesized $\mathrm{Ni}-\mathrm{Mg}(\mathrm{Ca})-\mathrm{Al} 2 \mathrm{O} 3$ as effective and remarkably stable catalysts for combined steam and dry reforming of methane (CSDRM) Appl Catal B Environ, https://doi.org/10.1016/j.apcatb.2016.08.009.

45. Bengaard, H.S., Nørskov, J.K., Sehested, J., Clausen, B.S., Nielsen, L.P., Molenbroek, A.M. \& Rostrup-Nielsen, J.R. (2002). Steam reforming and graphite formation on Ni catalysts J. Catal., https://doi.org/10.1006/jcat.2002.3579.

46. Bej, B., Pradhan, N.C. \& Neogi, S. (2013). Production of hydrogen by steam reforming of methane over alumina supported nano-NiO / $\mathrm{SiO} 2$ catalyst Catal. Today, https://doi. org/10.1016/j.cattod.2012.04.011.

47. Zhang, Y., Wang, W., Wang, Z., Zhou, X., Wang, Z. \& Liu, C.J. (2015). Steam reforming of methane over $\mathrm{Ni} / \mathrm{SiO} 2$ catalyst with enhanced coke resistance at low steam to methane ratio Catal. Today 256, 130-136, https://doi.org/10.1016/J. CATTOD.2015.01.016.

48. Nieva, M.A., Villaverde, M.M., Monzón, A., Garetto T,F. \& Marchi, A.J. (2014). Steam-methane reforming at low temperature on nickel-based catalysts Chem. Eng. J., https:// doi.org/10.1016/j.cej.2013.09.030.

49. Amjad, UES., Vita, A., Galletti, C., Pino, L. \& Specchia, S. (2013). Comparative study on steam and oxidative steam reforming of methane with noble metal catalysts Ind. Eng. Chem. Res., https://doi.org/10.1021/ie400679h.

50. Amjad, U.E.S., Gonçalves Lenzi, G., Camargo FernandesMachado, N.R. \& Specchia, S. (2015). MgO and Nb oxides used as supports for Ru-based catalysts for the methane steam reforming reaction Catal. Today, https://doi.org/10.1016/j.cattod.2015.02.010.

51. Roy, P.S., Park, N.K. \& Kim, K. (2014). Metal foamsupported $\mathrm{Pd}-\mathrm{Rh}$ catalyst for steam methane reforming and its application to SOFC fuel processing Int. J. Hydrogen Energy, https://doi.org/10.1016/j.ijhydene.2014.01.004.

52. Hiramitsu, Y., Demura, M., Xu, Y., Yoshida, M. \& Hirano, T. (2015). Catalytic properties of pure Ni honeycomb catalysts for methane steam reforming Appl. Catal. A. Gen., https://doi.org/10.1016/j.apcata.2015.09.044.

53. Vita, A., Italiano, C., Ashraf, M.A., Pino, L. \& Specchia, S. (2018). Syngas production by steam and oxy-steam reforming of biogas on monolith-supported $\mathrm{CeO} 2$-based catalysts Int. J. Hydrogen Energy, https://doi.org/10.1016/j.ijhydene.2017.11.140.

54. Khani, Y., Shariatinia, Z. \& Bahadoran, F. (2016). High catalytic activity and stability of $\mathrm{ZnLaAlO} 4$ supported $\mathrm{Ni}, \mathrm{Pt}$ and $\mathrm{Ru}$ nanocatalysts applied in the dry, steam and combined dry-steam reforming of methane Chem. Eng. J., https://doi. org/10.1016/j.cej.2016.04.108.

55. Kho, E.T., Lovell, E., Wong, R.J., Scott, J. \& Amal, R. (2017). Manipulating ceria-titania binary oxide features and their impact as nickel catalyst supports for low temperature steam reforming of methane Appl. Catal. A. Gen., https://doi. org/10.1016/j.apcata.2016.11.019.

56. Lim, Z.Y., Wu, C., Wang, W.G., Choy, K.L. \& Yin, H. (2015). Porosity effect on $\mathrm{ZrO} 2$ hollow shells and hydrothermal stability for catalytic steam reforming of methane J. Mater. Chem. A., https://doi.org/10.1039/c5ta07015e.

57. Hagen, J. (2015). Industrial catalysis: A practical approach Ind. Catal. A Pract. Approach., https://doi. org/10.1002/9783527684625.

58. Öhlmann, G. (1999) Handbook of Heterogeneous Catalysis Zeitschrift für Phys. Chemie, https://doi.org/10.1524/ zpch.1999.208.Part_1_2.274. 